\title{
Perhitungan Potensi Limbah Padat Kelapa Sawit untuk Sumber Energi Terbaharukan dengan Metode LCA
}

\section{Palm Solid Wastes Potential Calculation for Renewable Energy with LCA Method}

\author{
JOKO PRAYITNO SUSANTO ${ }^{1^{\star}}$, ARIF DWI SANTOSO ${ }^{1}$ DAN NAWA SUWEDI ${ }^{1}$ \\ ${ }^{1}$ Peneliti Pusat Teknologi Lingkungan, BPPT \\ Gedung 820 Geostek, Kawasan Puspiptek Serpong, Tangerang Selatan \\ *joko.susanto@bppt.go.id
}

\begin{abstract}
The production process of crude palm oil (CPO) or palm oil biodiesel produces byproduct of solid waste of about $35-40 \%$ of the total fresh fruit bunches (FFB). Those are empty fruit bunches (EFB), fiber, shells and ash. These wastes could potentially pollute the environment if they are not properly managed. This paper will discuss and calculate the potential of the palm solid wastes as renewable energy and their impact on the increasing value of net energy balance (NEB) and net energy ratio (NER). Mass balance data of palm solid wastes was calculated using life cycle assessment (LCA) method and it is then converted to the energy factor found from reliable sources of references. Results of the study state that the total solid wastes of fiber and shell produced from 1 (one) ton of TBS is $130 \mathrm{~kg}$ and $65 \mathrm{~kg}$, respectively. If these wastes are used as fuel for the boiler they will contribute to energy of $10,118 \mathrm{MJ} /$ ton biodiesel. The addition of this renewable energy will significantly increase the value of NEB and NER. The value of NEB is estimated to be from 27,199 to $37,317 \mathrm{MJ}$ or increase by $37,2 \%$ whereas value of NER is estimated to be from 3.19 to 4.01 or increase by $25,5 \%$.
\end{abstract}

Keywords: CPO, biodiesel, palm oil, palm solid waste, NER, NEB, LCA

\begin{abstract}
ABSTRAK
Proses produksi crude palm oil (CPO) dan biodiesel kelapa sawit menghasilkan limbah padat sebanyak $35-40 \%$ dari total tandan buah segar (TBS) yang diolah, dalam bentuk tandan buah kosong, serat, cangkang buah dan abu bakar. Keberadaan limbah yang melimpah ini berpotensi mencemari lingkungan bila tidak tertangani dengan baik. Penelitian ini bertujuan untuk membahas dan menghitung potensi limbah padat sawit menjadi energi terbarukan dan pengaruhnya terhadap peningkatan nilai net energy ratio (NER) dan net energy balance (NEB). Dalam penelitian ini digunakan metode life cycle assessment (LCA) untuk menghitung neraca limbah padat yang hasilnya akan dikonversikan ke dalam nilai faktor energi dari sumber pustaka yang terpercaya. Hasil neraca massa limbah sawit menunjukkan bahwa total limbah padat serat dan cangkang yang dihasilkan setiap pengolahan 1 ton TBS adalah $130 \mathrm{~kg}$ dan $65 \mathrm{~kg}$. Limbah ini bila digunakan sebagai bahan bakar boiler akan berpotensi menghasilkan energi sebesar $10.118 \mathrm{MJ} /$ ton biodiesel. Tambahan energi terbarukan ini akan meningkatkan nilai NER dan NEB secara signifikan. Nilai NEB naik 27.199 MJ menjadi sekitar 37.317 MJ (37,2\%) dan nilai NER naik dari 3,19 menjadi 4,01 atau meningkat $25,5 \%$.
\end{abstract}

Kata kunci : CPO, biodiesel, kelapa sawit, limbah padat sawit, NER, NEB, LCA

\section{PENDAHULUAN}

\subsection{Latar Belakang}

Industri kelapa sawit Indonesia merupakan salah satu industri strategis penyumbang devisa bagi negara dari sektor non-migas. Pada tahun 2016, Badan Pengelola Perkebunan Dana Sawit (BPDP Sawit) mencatat ekspor sawit Indonesia mencapai 25,7 juta ton atau senilai US\$ 17,8 miliar atau sekitar Rp 240 triliun. Perkembangan industri kelapa sawit Indonesia terus meningkat dan menjadi negara produsen CPO terbesar di dunia dengan total produksi sebesar 32 juta ton atau sekitar $46,6 \%$ dari total produksi CPO dunia $^{(1)}$. Permintaan pasar dunia terhadap CPO terus meningkat. Data dari world statistik menyebutkan bahwa estimasi kebutuhan CPO dunia pada tahun 2020 sebesar 95,7 juta ton ${ }^{(2)}$. Kondisi ini menunjukkan bahwa masa depan industri kelapa sawit Indonesia berpotensi untuk terus berkembang untuk mencukupi kebutuhan CPO dunia.

Selain semakin meningkatnya produksi dan proyeksi pasar industri sawit yang cerah, di sisi lain pabrik sawit dapat menimbulkan masalah yakni adanya peningkatan volume limbahnya. 
Proses pengolahan minyak kelapa sawit menghasilkan limbah padat, cair dan gas ${ }^{(3)}$. Limbah padat ini antara lain adalah tandan kosong, cangkang/fiber, abu boiler, solid decanter, sampah loading ramp dan shell. Limbah cair merupakan sisa dari proses pembuatan minyak kelapa sawit berbentuk cair yang disebut POME (palm oil mills effluent). Sedangkan limbah gas berasal dari gas buangan pabrik kelapa sawit pada proses produksi CPO ${ }^{(4)}$.

Pengolahan 1 (satu) ton tandan buah segar (TBS) kelapa sawit akan menghasilkan limbah berupa tandan kosong kelapa sawit sebanyak $23 \%$ atau $230 \mathrm{~kg}$, limbah cangkang (shell) sebanyak $6,5 \%$ atau $65 \mathrm{~kg}$, wet decanter solid (lumpur sawit) $4 \%$ atau $40 \mathrm{~kg}$, serabut (fiber) $13 \%$ atau $130 \mathrm{~kg}$ serta limbah cair sebanyak $50 \%{ }^{(5)}$. Dari data limbah padat yang dihasilkan tersebut dapat diperkirakan jumlah limbah padat yang dihasilkan oleh sebuah pabrik kelapa sawit yang berkapasitas 50 ton per jam, yaitu 23.250 ton/hari. Besarnya limbah padat yang tidak diolah secara maksimal ini tentu akan menimbulkan permasalahan lingkungaan bagi industri dan pada akhirnya akan mengurangi daya saing dan produktifitas industri sawit Indonesia.

Pada paper ini penulis akan menghitung potensi limbah padat sawit sebagai energi terbarukan dengan menggunakan metode LCA untuk menghitung energi yang diperlukan berbasis perhitungan memproduksi 1 (satu) ton biodiesel. Dalam beberapa penelitian sebelumnya, penghitungan energi ini telah dilakukan oleh beberapa peneliti yang berbasis perhitungan pada luas lahan ${ }^{(6,7)}$, berdasarkan input TBS ${ }^{(8)}$, dll.

Berbeda dengan peneliti sebelumnya ${ }^{(8)}$, dalam penelitian ini, perhitungan potensi energi difokuskan pada dua komponen limbah kelapa sawit, yaitu serat dan cangkang (tanpa memperhitungkan potensi energi dari tandan kosong), untuk menjadi bahan bakar boiler sebagai sumber energi terbarukan pengganti energy fosil.

Hasil penelitian ini diharapkan menjadi acuan bagi praktisi sawit untuk dapat lebih memanfaatkan limbah padat dari industri sawit secara lebih optimal sebagai upaya untuk mendukung pembangunan yang berkelanjutan melalui pengurangan penggunakaan bahan bakar fosil

\subsection{Studi Literatur}

\section{a. Jenis dan Potensi Limbah Kelapa Sawit}

Jenis dan potensi pemanfaatan limbah pabrik kelapa sawit dapat digambarkan bentuk pohon industri sebagaimana disajikan dalam gambar 1 .

Industri sawit, sejak dari budidaya hingga produksi minyak sawit (CPO) menghasilkan berbagai limbah terdiri dari limbah padat, limbah cair dan limbah gas. Limbah padat terdiri dari tandan kosong, pelepah, cangkang (shee/), serat (fiber), lumpur sawit (Wet Decanter Solid) dan lain-lain. Limbah cair terjadi pada in house keeping pada pengolahan CPO yaitu POME ${ }^{(5)}$.

Pemanfaatan limbah baik padat maupun cair secara umum dapat dilakukan melalui proses pengolahan yang dapat dibedakan dalam tiga proses yakni: proses kimia, proses fisika serta proses biologi.

Dari literatur diketahui bahwa persentase tandan kosong terhadap TBS sekitar $20 \%$ dan setiap ton tandan kosong mengandung unsur hara $\mathrm{N}, \mathrm{P}, \mathrm{K}$, dan $\mathrm{Mg}$ berturut-turut setara dengan $3 \mathrm{Kg}$ Urea; 0,6 Kg CIRP; $12 \mathrm{Kg}$ MOP; dan $2 \mathrm{Kg}$ Kieserit $^{(10)}$. Dengan kandungan unsur hara ini, tandan kosong selain bepotensi sebagai sumber energi juga dapat dimanfaatkan sebagai kompos yang dapat digunakan untuk pemupukan kelapa sawit.

\section{b. Karakteristik Limbah Padat Kelapa Sawit}

Proses pengolahan TBS pada industri Kelapa Sawit yang menghasilkan produk minyak sawit mentah/ CPO dan minyak inti sawit (kernel inti sawit) akan selalu menghasilkan limbah, antara lain limbah padat dalam bentuk tandan kosong, cangkang sawit, serat, dan wet decanter solid (lumpur sawit).

Tandan kosong merupakan limbah dari pabrik minyak kelapa sawit (PKS) setelah TBS melalui proses sterilizer dan tippler. Jumlah tandan kosong yang dihasilkan setiap ton TBS yang diolah mencapai sekitar $23 \%$, namun belum banyak dimanfaatkan dan pengelolaannya masih terbatas hanya dibakar dan sebagian dibiarkan sebagai mulsa tanaman. Tandan kosong mengandung selulosa 41,3\%-46,5\% $\left(\mathrm{C}_{6} \mathrm{H}_{10} \mathrm{O}_{5}\right) \mathrm{n}$, hemi selulosa $25,3 \%-32,5 \%$ dan lignin 27,6\%$32,5 \%{ }^{(5)}$. Dengan kandungan ini, tandan kosong disamping mempunyai potensi sebagai sebagai sumber energi( ${ }^{(8)}$, juga berpotensi untuk dimanfaatkan sebagai kompos untuk mengatur kelembaban tanah, meningkatkan infiltrasi tanah, menambah bahan organik tanah, meningkatkan KTK tanah, menstabilkan temperatur tanah, memperbaiki struktur tanah, meningkatkan mikroba tanah dan mengendalikan laju aliran permukaan dan erosi tanah ${ }^{(4)}$.

Cangkang merupakan limbah yang dihasilkan dari pemrosesan kernel inti sawit dengan bentuk seperti tempurung kelapa, mempunyai kalor $3.500 \mathrm{kkal} / \mathrm{kg}-4.100 \mathrm{kkal} / \mathrm{kg}^{(11)}$. Cangkang sawit atau tempurung kelapa sawit merupakan bagian paling keras pada komponen yang terdapat pada kelapa sawit yang pemanfaatannya pada industri pengolahan minyak CPO belum maksimal. Cangkang sawit mempunyai potensi untuk digunakan sebagai 
bahan arang maupun bahan bakar untuk boiler. Dibandingkan dengan batu bara, cangkang kelapa sawit memiliki kelebihan sebagai bahan bakar yang ramah terhadap lingkungan karena tidak mengandung sulfur sehingga tidak menghasilkan gas pencemar $\left(\mathrm{SO}_{2}\right)$. Saat ini pemanfaatan cangkang sawit di berbagai industri pengolahan minyak CPO masih belum dilakukan untuk substitusi energi dalam proses industri, tetapi masih sebagai produk samping yang dijual ke pasaran dalam bentuk cangkang sawit ${ }^{(12)}$.

Dalam proses produksi CPO juga dihasilkan limbah serat yang merupakan sisa perasan buah sawit berupa serabut seperti benang yang memiliki kandungan protein kasar sekitar $4 \%$ dan serat kasar $36 \%$ (lignin 26\%) serta mempunyai kalor $2.637-3.998 \mathrm{kkal} / \mathrm{kg}^{(11)}$.

Disamping ketiga jenis limbah padat di atas, dalam proses pengolahan minyak sawit (CPO) dihasilkan limbah cair sangat banyak, yaitu sekitar $2,5 \mathrm{~m}^{3} /$ ton produksi CPO yang mengandung bahan pencemar sangat tinggi, yaitu biochemical oxygen demand (BOD) sekitar $20.000-60.000 \mathrm{mg} / \mathrm{I}^{(13)}$. Melalui proses decanter untuk mengurangi kadar cairan dihasilkan lumpur sawit (Wet Decanter Solid) yang memiliki kandungan air sekitar $75 \%$, protein kasar $11,14 \%$ dan lemak kasar $10,14 \%{ }^{(11)}$.

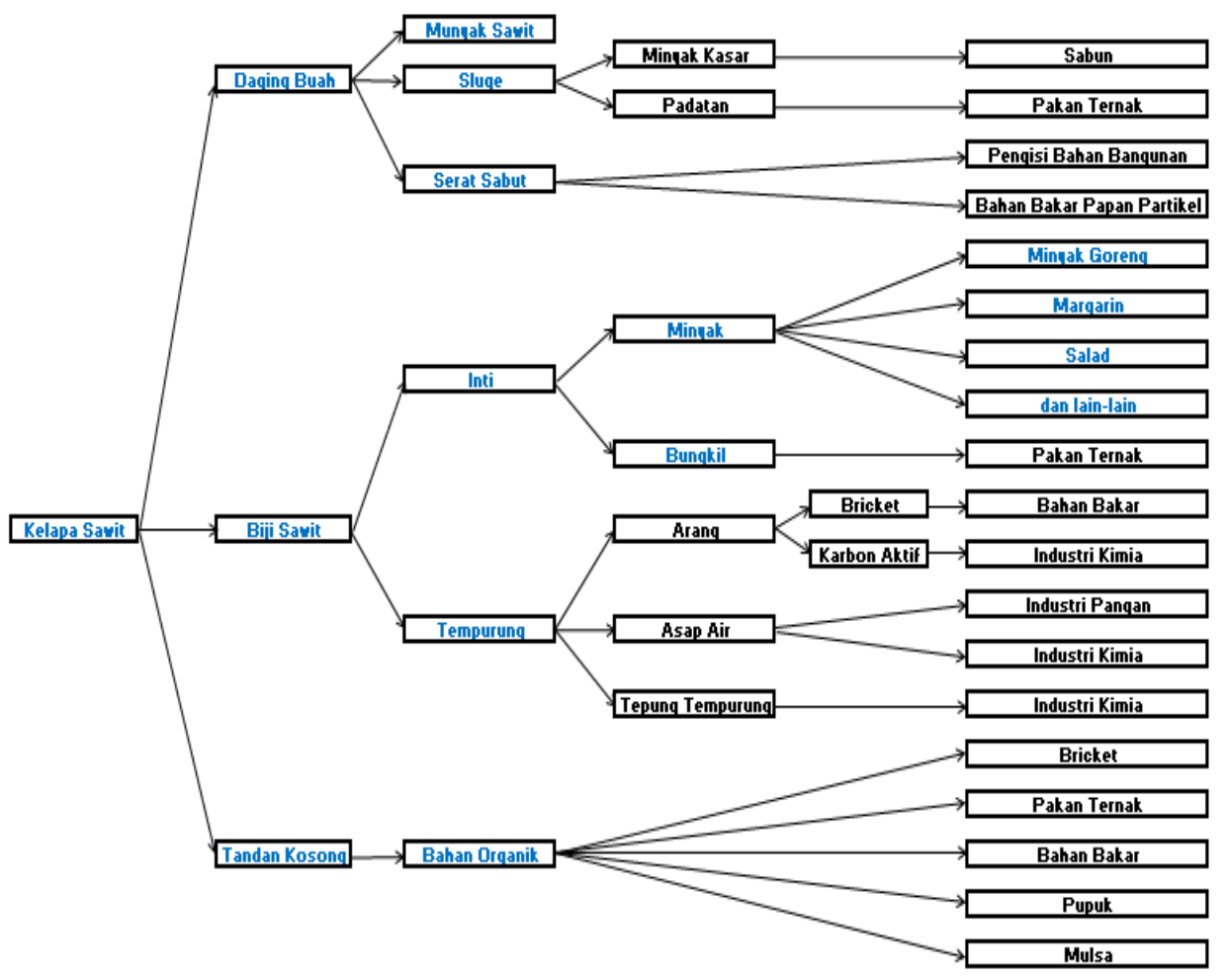

Gambar 1. Pohon industri pemanfaatan limbah pabrik kelapa sawit ${ }^{(9)}$

\subsection{Tujuan}

Penelitian ini bertujuan untuk membahas dan menghitung potensi limbah padat sawit menjadi energi terbarukan dan pengaruhnya terhadap peningkatan nilai net energy balance (NEB) dan net energy ratio (NER)

\section{BAHAN DAN METODE}

\subsection{Bahan}

Dalam penelitian ini digunakan inventory data input dan output produksi 1 ton biodiesel yang diadaptasi dari beberapa literatur. Data tersebut kemudian dikonversi ke dalam nilai energi yang mengacu pada skala fungsional unit (FU) pada tabel 3.
Tabel 3. Nilai konversi energi limbah padat kelapa sawit

\begin{tabular}{lcc}
\hline Variabel & Unit & Energi (MJ/kg) \\
\hline Serat & $\mathrm{Kg}$ & 7,70 \\
Cangkang & $\mathrm{Kg}$ & 11,91 \\
\hline${ }^{*}$ de Sauza et al., 2010 & ${ }^{(1) ;}$ Mahlia et al., 2001 \\
\end{tabular}

Nilai konversi energi dari serat dan cangkang ini telah memperhitungkan efisiensi boiler sebesar $68 \%{ }^{(7,14)}$.

\subsection{Metode}

\section{a. Pengumpulan dan Analisis Data}

Data dikumpulkan dari beberapa literatur yang memfokuskan pada pengelolaan limbah 
padat dari pabrik kelapa sawit dengan kapasitas penanganan TBS sebanyak 50 ton/hari. Perhitungan potensi energi didasarkan kebutuhan energi yang digunakan untuk produksi 1 ton biodiesel dengan melakukan analisa terhadap semua material, energi, dan limbah dari proses produksi biodiesel. Data-data ini dikumpulkan dan divalidasi dari data literatur yang up to date dan terpercaya.

\section{b. Perhitungan NER dan NEB}

Dalam penelitian ini, digunakan metode LCA berdasarkan ISO 14040 framework ${ }^{(15)}$, khususnya untuk analisis siklus energi (Life-cycle energy analysis) dalam hal ini untuk menghitung NER dan NEB produksi biodiesel dari kelapa sawit. NEB adalah perbedaan antara total energi output (meliputi energi yang terkandung dalam produk biodiesel dan/atau produk samping) dan total energi input. Nilai NEB merupakan salah satu indeks yang biasa digunakan untuk menganalisis efisiensi energi dari biofuel ${ }^{(16)}$. Sedangkan NER adalah rasio dari total energi output terhadap total energi input yang mencerminkan efisiensi energi proses. Kedua nilai NEB dan NER akan digunakan sebagai indikator untuk mengevaluasi hasil dari analisis siklus energi ${ }^{(6)}$.

\section{HASIL DAN PEMBAHASAN}

\subsection{Inventori Energi}

Limbah padat kelapa sawit, seperti serat dan cangkang merupakan material padatan yang mengandung persentase volume karbon yang tinggi dan dapat dikonversi sebagai sumber energi panas dengan reaksi termal ${ }^{(17)}$. Kelimpahan limbah ini berpotensi untuk dimanfaatkan menjadi salah satu dari bahan bakar terbarukan utama untuk industri sawit masa depan. Namun, efisiensi pembakaran bahan bakar ini perlu ditingkatkan untuk mengurangi emisi berbahaya yang dipancarkan ke atmosfer, terutama emisi partikulat atau $\operatorname{asap}^{(18)}$.

Untuk mengetahui neraca energi yang diperlukan sejak budidaya sawit hingga produksi biodiesel (energi input) terhadap energi yang terkandung dalam biodiesel (energi output), dalam penelitian ini dilakukan pengolahan data dari berbagai literature terpercaya yang hasil olahan datanya disajikan pada tabel $4^{(6,7,19)}$.

Untuk memudahkan pengelompokan dan analisis, variabel input dikelompokkan dalam beberapa sub variable input, antara lain pupuk, pestisida, transportasi, produksi CPO dan produksi biodiesel (Gambar 2).

Dari hasil olahan data tersebut dapat diketahui bahwa pada tahap budidaya konsumsi energi banyak digunakan pada proses pemupukan. Penggunaan pupuk nitrogen (urea) selama kegiatan budidaya menyerap energi sebesar $2.490 \mathrm{MJ} /$ ton produksi biodiesel. Kebutuhan transportasi selama budidaya dan produksi di pabrik membutuhkan energi sebesar 196 MJ atau sekitar 1,6\%. Kebutuhan energi ini digunakan untuk mobilisasi TBS dari kebun ke pabrik, proses pengangukan CPO ke pabrik biodiesel serta transportasi lain.

Tabel 4. Inventaris data input dan output produksi 1 ton biodiesel

\begin{tabular}{ccc}
\hline $\begin{array}{c}\text { Life Cycle Biodiesel } \\
\text { Production }\end{array}$ & $\begin{array}{c}\text { Per ton } \\
\text { PME }\end{array}$ & $\begin{array}{c}\text { MJ/ton } \\
\text { PME }\end{array}$ \\
\hline
\end{tabular}

Input (satuan)

a. Pupuk

$\begin{array}{lrr}\text { Nitrogen }(\mathrm{kg}) & 75,00 & 2.490,00 \\ \text { Fosfat }(\mathrm{kg}) & 8,00 & 22,40 \\ \text { Kalium }(\mathrm{kg}) & 70,00 & 245,00 \\ \text { Magnesium }(\mathrm{kg}) & 42,00 & 21,00 \\ \text { Sub total }(\mathbf{k g}) & & \mathbf{2 . 7 7 8 , 4 0}\end{array}$

b. Pestisida

Paraquat $(\mathrm{kg}) \quad 0,40 \quad 183,36$

Glyshopate $(\mathrm{kg}) \quad 1,20 \quad 543,00$

Sub total $\quad \mathbf{7 2 6 , 3 6}$

c. Transportasi (I diesel)

Sub total

4,75

196,32

d. Produksi CPO

Listrik (kWh)

Steam $\left(\mathrm{m}^{3}\right)$

Diesel (I)

Sub total

$140,00 \quad 1.465,80$

$0,50 \quad 1.302,00$

$7,00 \quad 289,31$

$3.057,11$

e. Produksi Biodiesel

Listrik (kWh)

Metanol (kg)

80,00

837,60

$\mathrm{NaOH}(\mathrm{kg})$

140,00

$4.690,00$

Sub total

$5.645,80$

Total Energi Input

$(\mathrm{I}+\mathrm{II}+\mathrm{III+IV+V)}$

12.403,99

\section{Output (satuan)}

Palm methyl ester $\quad 1.000,00 \quad 39.600,00$

(PME) (kg)

Total Energi

$39.600,00$ 


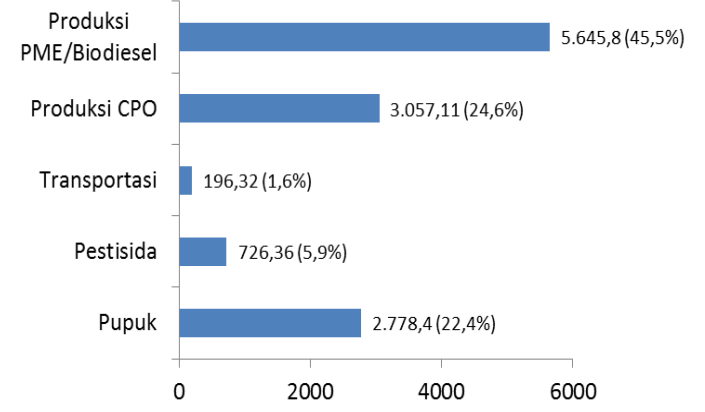

Gambar 2. Prosentase kebutuhan energi setiap tahap pada produksi biodiesel kelapa sawit

Dari tabel 4 di atas, maka neraca energi yang diperoleh dari energi input untuk budidaya sawit hingga produksi biodiesel dan energi output yang terkandung dalam 1 ton biodiesel, dan selanjutnya disebut sebagai neraca energi BAU (Business as usual) masing-masing adalah NEB $\mathrm{BAU}=27.196,01 \mathrm{MJ}$ dan NER BAU = 3,19.

Tahap sub produksi biodiesel merupaka sub produksi yang menyerap energi paling besar yaitu sebesar 5.645,8 MJ (45,5\%). Tingginya energi ini dikontribusikan oleh penggunaan metanol sebagai bahan katalis pada proses transterifikasi.

Kebutuhan energi yang besar juga terjadi selama proses produksi CPO yakni sebesar $3.057 \mathrm{MJ}$ atau sekitar 25\%. Energi sebesar ini banyak digunakan untuk proses sterilisasi TBS, proses klarifikasi minyak dan keperluan lain yang membutuhkan listrik. Tingginya energi yang dibutuhkan pada sub proses ini dapat dikurangi dengan mengganti sebagian bahan bakar fossil dengan bahan bakar terbarukan dari limbah padat serat dan cangkang.

\subsection{Potensi Energi dari Limbah Padat}

Dalam penelitian ini, dihitung potensi energi dari penggunaan dua komponen limbah kelapa sawit, yaitu serat dan cangkang, untuk menjadi bahan bakar boiler sebagai sumber energi terbarukan pengganti energy fosil. Dengan menggunakan nilai konversi energi sebagaimana disajikan dalam tabel 3 dan hasil perhitungan berat masing-masing limbah padat yang dihasilkan untuk produksi 1 ton PME, maka potensi energi yang dapat diperoleh dari pemanfaatan limbah serat dan cangkang sebagai bahan bakar adalah 10.118,4 MJ/ton produksi biodiesel. Potensi energi dari serat dan cangkang ini merupakan potensi energi riil yang dapat digunakan setelah memperhitungkan efisiensi boiler sebesar $68 \%{ }^{(7,14)}$. Secara lengkap disajikan dalam tabel 5 .
Tabel 5. Perhitungan potensi enegi dari limbah padat sawit per ton produksi PME.

\begin{tabular}{lrrc}
\hline $\begin{array}{l}\text { Input } \\
\text { Material }\end{array}$ & $\begin{array}{c}\text { Faktor Energi } \\
(\mathrm{MJ} / \mathrm{kg})\end{array}$ & $\begin{array}{c}\text { Berat }(\mathrm{kg}) / \\
\text { Ton PME }\end{array}$ & $\begin{array}{c}\text { Potensi Energi } \\
(\mathrm{MJ} / \text { ton PME) }\end{array}$ \\
\hline Serat & 7,70 & 741,0 & $5.705,7$ \\
\hline Cangkang & 11,91 & 370,5 & $4.412,7$ \\
\hline & Jumlah & & $\mathbf{1 0 . 1 1 8 , 4}$ \\
\hline
\end{tabular}

Di samping potensi energi dari limbah serat dan cangkang ini cukup tinggi, penggunaan kedua jenis limbah ini sebagai bahan bakar boiler memiliki beberapa keunggulan. Beberapa alasan tentang sisi positif dari penggunaan limbah biomassa kelapa sawit seperti serat dan cangkang menjadi energi tambahan dalam industri kelapa sawit antara lain ${ }^{(14)}$ :

1. Biomassa limbah ini tidak menyebabkan tambahan gas rumah kaca di atmosfir.

2. Limbah ini bila digunakan sebagai bahan bakar akan mengurangi potensi akumulasi gas $\mathrm{CH} 4$ akibat proses dekomposisi limbah. $\mathrm{CH}_{4}$ ini berpotensi meningkatkan GRK 21 kali lebih besar dibanding $\mathrm{CO}_{2}$

3. Biomassa ini tidak mengandung senyawa sulfur, sehingga bila dibakar dalam jumlah besar tidak menimbulkan polusi oksida sulfur yang membahayakan kesehatan.

4. Abu dari hasil pembakaran biomassa ini bersifat normal alkaline, artinya bila diaplikasikan dalam lahan pertanian tidak akan menimbulkan pengasaman tanah.

5. Penggunaan biomassa sebagai bahan bakar dalam jumlah besar akan mengurangi timbunan limbah di sekitar pabrik, sehingga dapat meningkatkan produktifitas pabrik secara kontinyu.

\subsection{Perhitungan NEB dan NER}

Dengan menggunakan hasil perhitungan potensi enegi dari limbah padat sawit sebagaimana telah disampaikan dalam tabel 5 , maka nilai NEB dan NER yang diperoleh dari perhitungan berdasarkan metode $\mathrm{LCA}^{(5,15)}$ masing-masing adalah 37.317 $\mathrm{MJ}$ dan 4,01 per ton produksi biodiesel.

Dengan inovasi pemanfaatan limbah tersebut juga mengeser nilai NEB dan NER yang cukup signifikan. Nilai NEB per ton produksi biodiesel kelapa sawit naik dari 27.199 MJ menjadi sekitar 37.317 MJ. Sedangkan nilai NER naik sekitar $25,5 \%$ dari 3,19 menjadi 4,01. Namun demikian, nilai NEB dan NER dari produksi biodiesel kelapa sawit masih bisa ditingkatkan misalnya dengan mengefisienkan penggunaan energi listrik dan bahan bakar fosil, memanfaatkan limbah lainnya untuk proses produksi misalnya limbah metanol dapat diolah dan dipakai lagi dalam proses produksi. Upaya lain untuk meningkatkan nilai 
NEB dan NER adalah menambah variasi produk samping seperti produksi gas, dan pemanfaatan limbah biomas untuk keperluan ekonomis yang lain.

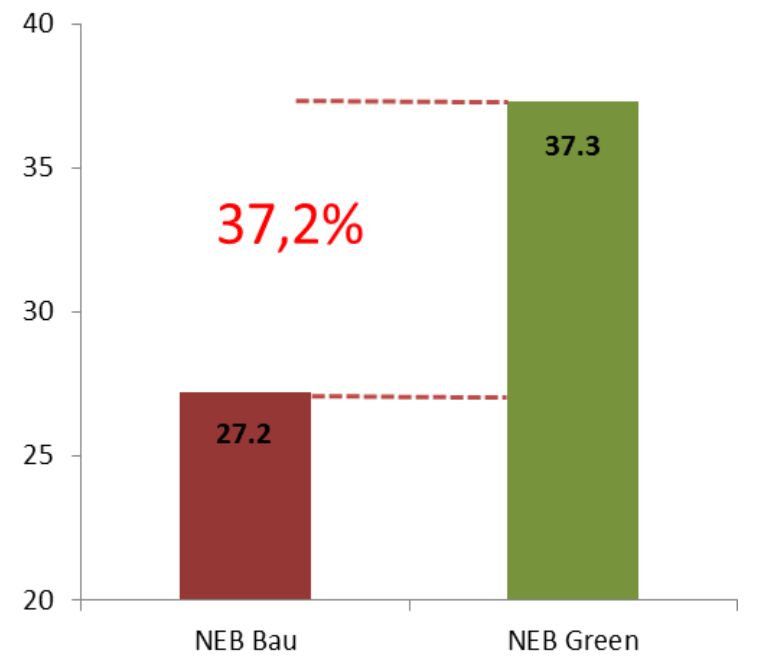

Gambar 3. Kenaikan nilai NEB akibat pemanfaatan limbah padat

Keterangan :

- NEB BAU : tanpa memanfaatkan serat dan cangkang sebagai sumber energi;

- NEB Green : setelah aplikasi dengan memanfaatkan serat dan cangkang sebagai sumber energi

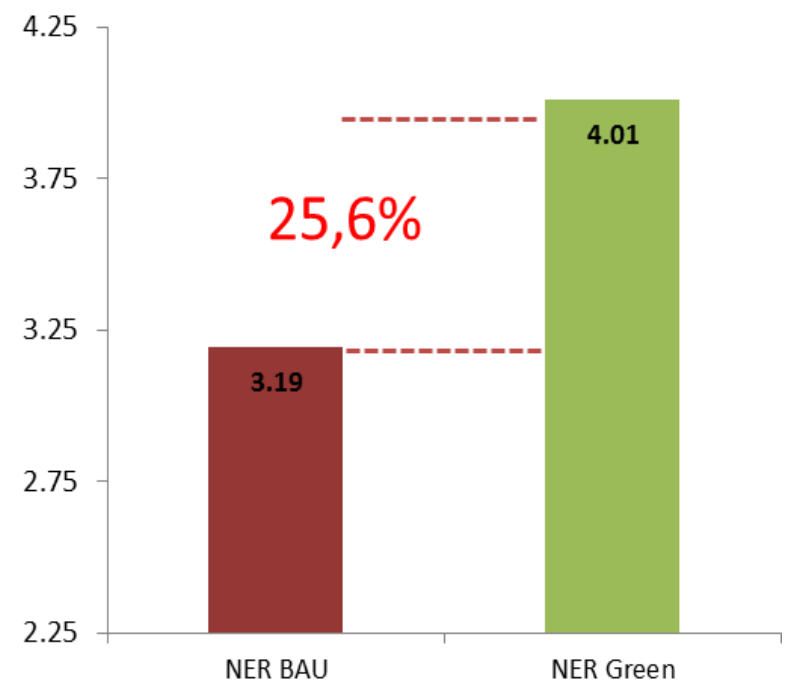

Gambar 4. Kenaikan nilai NER akibat pemanfaatan limbah padat

Keterangan :

- NER BAU : tanpa memanfaatkan serat dan cangkang sebagai sumber energi;

NER Green : setelah aplikasi dengan memanfaatkan serat dan cangkang sebagai sumber energi

\subsection{Pembahasan Umum}

Upaya pengelolaan limbah padat menghasilkan dua keuntungan bagi industri kelapa sawit, yaitu keuntungan berupa tambahan energi dan partisipasi dalam pengurangan limbah di sekitar pabrik/kebun.

Potensi energi riil dari hasil pengolahan limbah padat yang dapat ditambahkan setelah memperhitungkan efisiensi boiler sebesar $68 \%^{(7,14)}$ adalah sekitar $10.118 \mathrm{MJ} /$ ton produksi biodiesel dari total kebutuhan energi input sebesar $12.403 \mathrm{MJ}$. Peneliti lain yang melakukan inovasi yang sama, menghasilkan tambahan energi sebesar $11.710 \mathrm{MJ} / \mathrm{ton}$ produksi biodiesel $^{(20)}$, dan $15.870 \mathrm{MJ} /$ ton produksi biodiesel $^{(21)}$. Energi tambahan dari peneliti luar ini relatif besar dibanding dengan perhitungan penulis, karena kedua peneliti asing memperhitungkan limbah tandan buah kosong dalam perhitungannya. Namun, secara umum dapat dipastikan bahwa tambahan energi yang didapat dari inovasi ini merupakan bonus, yang dipentingkan dalam pengelolaan limbah padat ini adalah upaya pengelolaan limbah agar keberadaannya tidak menggangu lingkungan dan sebagai persyaratan kelaikan beroperasinya pabrik kelapa sawit secara berkelanjutan.

Upaya pengelolaan limbah padat sawit juga dapat meningkatkan nilai NEB dan NER secara signifikan. Nilai NEB dan NER per ton produksi biodiesel masing-masing naik secara signifikan dari 27.199 MJ menjadi sekitar 37.317 MJ $(37,2 \%)$ dan 3,19 menjadi 4,01 (25,6 \%). Peningkatan nilai NEB dan NER dapat menjadi pertimbahan stakeholder sawit untuk melakukan hal yang sama. Nilai ini menjadi acuan bahwa produk biodiesel sawit dinilai mempunyai siklus energi yang positif. Nilai NEB dan NER per ton produksi biodiesel hasil penelitian ini tidak jauh berbeda dengan hasil penelitian Thamsiriroj, dkk. ${ }^{(22)}$ yaitu masing-masing $30.557 \mathrm{MJ}$ dan 3,58. Perbedaan nilai ini disebabkan karena dalam penelitiannya memperhitungkan juga limbah tandan kosong sebagai sumber energi. Dalam paper ini, penelitian potensi limbah padat sawit menjadi energi terbarukan hanya difokuskan pada limbah serat dan cangkang sawit dengan pertimbangan bahwa limbah tandan kosong memiliki kandungan air yang cukup tinggi sehingga pemanfaatannya sebagai bahan bakar boiler memerlukan perlakuan awal (pretreatment) untuk mengurangi kadar air sampai memenuhi kadar air minimal sebagai bahan bakar boiler.

Pemanfaatan limbah tandan kosong yang memiliki kandungan air tinggi ini akan lebih optimal digunakan sebagai kompos dengan memformulasikan bersama limbah cair $(\mathrm{POME})^{(23)}$. Limbah padat lainnya yang berupa lumpur sawit (Wet Decanter Solid) dapat digunakan sebagai pakan ternak karena kandungan nutrisi yang relatif tinggi ${ }^{(11)}$. 


\section{KESIMPULAN}

Pemanfaatan limbah padat kelapa sawit seperti serat dan cangkang sawit merupakan salah satu inovasi teknologi untuk meningkatkan produktivitas produk dari kelapa sawit. Keuntungan yang didapat adalah tambahan energi riil dan peningkatan kondisi lingkungan pabrik yang baik untuk keberlanjutan industri kelapa sawit. Tambahan energi riil yang didapat dari upaya ini adalah $10.118 \mathrm{MJ} /$ ton produksi biodiesel atau menaikkan net energy ratio (NER) sebesar $25,5 \%$.

\section{PERSANTUNAN}

Ucapan terima kasih disampaikan Kepada Badan Pengelola Dana Sawit (BPDPS), atas dukungan pembiayaannya terhadap penelitian ini melalui kegiatan Grant Research Sawit 2016 dengan judul kegiatan Penguatan Penggunaan Energi Biofuel Kelapa Sawit melalui Perhitungan LCA dan Budget Energi antara Biofuel Kelapa Sawit dan Bahan Bakar Fosil.

\section{DAFTAR PUSTAKA}

1. Anonim, (2016), Refleksi Industri Kelapa Sawit 2015 dan Prospek 2016, available from http://gapki.id/refleksi-industri-kelapasawit-2015-dan-prospek-2016, (viewed Nov 10, 2016).

2. Anonim, (2016), Demand for Indonesian Crude Palm Oil Fell in January 2016, available from https://www.indonesiainvestments.com/id/news/todaysheadlines/demand-for-indonesian-crudepalm-oil-fell-in-january-2016/item6521 (viewed June 12, 2017).

3. Fang, C. 2011. Comparison of UASB and EGSB reactors performance, for treatment of raw and deoiled palm oil mill effluent (POME). J. Hazard. Mater. 189:229-234. doi:10.1016/j.jhazmat.2011.02.025

4. Pahan, I., (2008), Kelapa Sawit. Penebar Swadaya, Jakarta.

5. Mandiri, (2012), Manual Pelatihan Teknologi Energi Terbarukan, Jakarta, DANIDA.

6. Pleanjai S., S.H. Gheewala, (2009), Full Chain Energy Analysis of Biodiesel Production from Palm Oil in Thailand, Applied Energy, 18 : 209-214.

7. Souza, S.P., S. Pacca, M. Turra de Avila, Borges J.L.B., (2010), Greenhouse gas emissions and energy balance of palm oil biofuel, Renewable Energy, 35, 2552-2561.

8. Bantacut, T., dan H. Pasaribu, (2015), Aliran Tertutup Massa Dan Potensi Mandiri Energi pada Produksi CPO, Jurnal Teknologi Industri Pertanian, 25 (3):215-226.

9. Anonim, (2011), Kelapa Sawit Dan Aneka Pengolahannya, available from https://lordbroken.wordpress.com/2011/01/0 8/kelapa-sawit-dan-aneka-pengolahannya (viewed April 24, 2017).

10. Singh, G., S. Manoharan, dan T. S. Toh, (1989), United plantations approach to palm oil mill by product management and utilization, Proceedings of International Palm Oil Development Conference, Palm Oil Research Institute of Malaysia, Kuala Lumpur, 225-234.

11. Haryanti, A., N. Norsamsi, P. S. F. Sholiha, N.P. Putri, (2012), Studi Pemanfaatan Limbah Padat Kelapa Sawit, Konversi, 3(2):20-29.

12. Purba, A.R., Akiyat, A.D. Koedadiri, E.S. Dja'far, Sutarta, I.Y. Harahap dkk., (2005), Budidaya Kelapa Sawit, Pusat Penelitian Kelapa Sawit, Medan, Hal. 1-2.

13. J. Chungsiriporn, S. Prasertsan, C. Bunyakan, (2006), Minimization of water consumption and process optimization of palm oil mills, Clean Technologies and Environmental Policy, 8(3): 151-158.

14. Mahlia, T.M.I., M.Z Abdulmuin, T.M.I Alamsyah, D Mukhlishien, (2001), An alternative energy source from palm wastes industry for Malaysia and Indonesia, Energy Conversion and Management, 42(18): 2109-2118.

15. Lee, K., and A. Inaba, (2004), Life Cycle Assessment Best Practices of ISO 14040 Series, Asia-Pacific Economic Co-operation, Singapore.

16. Nguyen, T.L.T., S.H. Gheewala, S. Garivait, (2007), Full chain energy analysis of fuel etanoffrom cassava in Thailand, Environ Sci Technol, 41(11), 4135-4142.

17. Nasrin, A.B., et.al, (2004), A systematic approach of assessing palm oil mills as RE power plant sites - a case study, Proceedings of the Advances in Malaysian Energy Research, $25-32$.

18. Mohamed, W., W.A. Najmi, (2001), Development and performance of a cascading hearth with secondary swirl combustor for solid waste (palm oil shells), Masters thesis, Universiti Teknologi Malaysia, UTM Skudai, Malaysia.

19. Silalertruksa, T., Gheewala S.H., (2012), Environmental sustainable assessment of 
palm biodiesel production in Thailand, Energy 43: 306-3014.

20. Papong, S., C. Tassaneewan, N. Soottiwan, M. Pomthong, (2010), Life cycle energy efficiency and potentials of biodiesel production from palm oil in Thailand, Energy policy 38: 226-233.

21. Pleanjai, S.H. \& Gheewala, S.H. (2009). Full chain energy analysis of biodiesel production from palm oil in Thailand. Appl Energy, 86, 209-214.
22. Thamsiriroj, T., J.D. Murphy, (2009, Is it better to import palm oil from Thailand to produce biodiesel in Ireland than to produce biodiesel from indigenous Irish rape seed?, Appl Energy, 86:595-604.

23. Hasanuddin, U., R. Sugiharto, A. Haryanto, T.Setiadi, K. Fujie, (2015), Palm oil mill effluent treatment and utilization to ensure the sustainability of palm oil industries, Water science and technology, 72.7: 10891095. 